\title{
MENINGKATKAN KEMAMPUAN BERPIKIR RASIONAL MAHASISWA MELALUI PEMBELAJARAN BLENDED LEARNING DENGAN VARIABEL MODERATOR KEMANDIRIAN BELAJAR
}

\author{
Oleh : Nova Pratiwi ${ }^{1}$, Januardi ${ }^{2}$ \\ (UNIVERSITAS PGRI PALEMBANG) \\ ${ }^{1)}$ vhapratiwi@gmail.com, ${ }^{2)}$ januardibkl@gmail.com
}

\begin{abstract}
Abstrak-Penelitian ini bertujuan untuk meningkatkan kemampuan berikir rasional mahasiswa pada mata kuliah statistik penelitian dengan menggunakan metode blended learning. Jenis penelitian ini adalah penelitian tindakan kelas, karena penelitian bertujuan untuk meningkatkan kemampuan berpikir rasional mahasiswa pendidikan akuntansi yang mengambil mata kuliah Statistik penelitian dan akan dilakukan perbaikan terhadap proses pembelajaran secara terus menerus selama penelitian. Pada penelitian ini, peneliti mengumpulkan data dengan melakukan tes untuk melihat kemampuan berpikir rasional mahasiswa mengenai materi yang telah dipelajari. Hasil penelitian menunjukkan persentase mahasiswa yang memperoleh nilai $\geq B$ 35,7 \% pada siklus I dan 83,3\% pada siklus II, artinya mahasiswa yang mendapatkan nilai $\geq B$ meningkat. Sehingga indikator keberhasilan yang diharapkan minimal 75\% sudah tercapai, maka penelitian tindakan kelas ini hanya sampai siklus ke II.
\end{abstract}

Kata Kunci: Blended Learning, Kemampuan Berpikir Rasional, Kemandirian Belajar

\begin{abstract}
This This study aims to improve the ability of students to think rationally in the research statistics course using the blended learning method. This type of research is classroom action research, because the research aims to improve the ability to think rationally of accounting education students who take Statistics research subjects and will make improvements to the learning process continuously during the research. In this study, researchers collected data by conducting tests to see students' rational thinking skills regarding the material they had learned. The results showed the percentage of students who got a value of nilai $B 35.7 \%$ in the first cycle and $83.3 \%$ in the second cycle, meaning that students who got the value of $\geq B$ increased. So that the expected success indicator of at least $75 \%$ has been achieved, then this class action research is only up to the second cycle.
\end{abstract}

Keywords: Blended Learning, Rational Thinking Ability, Learning Independence 


\section{PENDAHULUAN}

Statistika penelitian merupakan mata kuliah dasar penelitian yang sangat penting sebagai prasyarat untuk mengambil mata kuliah penelitian lanjutan berikutnya. Mata kuliah ini bertujuan untuk membekali mahasiswa agar memiliki kemampuan berpikir rasional, logis, kritis, kreatif, dan sistematis serta mampu menghasilkan mahasiswa yang mampu melaksanakan penelitian. Disamping itu juga perkuliahan statistik sebagai arena latihan mahasiswa untuk mampu memecahkan masalah kehidupan sehari-hari, mengenal pola-pola hubungan dan generalisasi pengalaman, dan pengembangan aktivitas. Salah satu hasil belajar yang diharapkan setelah mengikuti perkuliahan statistik penelitian ialah kemampuan mahasiswa dalam berpikir secara rasional, karena berpikir rasional erat kaitannya dengan kehidupan, merupakan jenis pemikiran yang dibutuhkan untuk mencapai suatu tujuan pembelajaran (Baron, 2008).

Berdasarkan hasil observasi yang telah dilakukan, dan juga pengalaman peneliti selama mengajar statistik penelitian, banyak mahasiswa yang tidak berani menampilkan hasil pekerjaannya, dan pada saat mengerjakan soal latihan terlihat beberapa mahasiswa kurang serius dan ketika diberikan tugas mandiri, sering kali mahasiswa hanya mengandalkan beberapa orang yang mengerjakan, selebihnya hanya menyalin tugas temannya, tentunya hal ini akan berakibat pada hasil belajar mahasiswa yang rendah. Pembelajaran yang berlangsung selama ini belum mampu menempatkan mahasiswa untuk terlibat aktif, berpikir dan mengkonstruksi pengetahuan. Kegiatan pembelajaran sering terhambat jika mahasiswa dihadapkan dengan latihan perhitungan statistik yang berujung pada ketidaktuntasan pembelajaran. Perkuliahan yang selama ini berlangsung belum menyentuh semua tingkat kognitif mahasiswa. Berdasarkan indikator berpikir rasional menurut (Novak, 1979) maka tingkat berpikir rasional mahasiswa yang menempuh mata kuliah statistik sebagai berikut: 
Tabel 1. Ketuntasan Berpikir Rasional Mahasiswa

\begin{tabular}{|l|c|}
\hline \multicolumn{1}{|c|}{ Indikator Kemampuan Berpikir Rasional } & Rata-Rata \\
\hline Mengingat & 8,5 \\
\hline Membayangkan & 8 \\
\hline Mengklasifikasi & 7,5 \\
\hline Menggeneralisasikan & 7,5 \\
\hline Membandingkan & 6,5 \\
\hline Mengevaluasi & 5 \\
\hline Menganalisis & 4,5 \\
\hline Mensintesis & 4,5 \\
\hline Mendeduksi & 4 \\
\hline Membuatkesimpulan & 4 \\
\hline
\end{tabular}

Sumber: Data diolah dari hasil ujian tengah semester

Tabel 1 menunjukkan bahwa kemampuan berpikir rasional mahasiswa masih rendah, mahasiswa hanya mampu menyelesaikan soalsoal indikator rasional rendah. Salah satu faktor yang menjadi permasalahan disini ialah mahasiswa kurang antusias memanfaatkan ruang dan kesempatan untuk mengeksplorasi informasi, menemukan pengalaman, mencoba memecahkan masalah dan mengembangkan kreativitas berpikir sesuai dengan kemampuan yang telah disediakan dosen dalam perkuliahan. Untuk meningkatkan kemampuan berpikir rasional maka mahasiswa membutuhkan metode pembelajaran yang mewadahi perbedaan cara belajar masingmasing, menantang kreativitas berpikir serta memfasilitasi keterlibatan aktif. Maka peneliti selaku dosen pengampuh mata kuliah akan mencoba mencarikan solusi untuk itu, melalui penerapan metode blended learning mahasiswa difasilitasi untuk mengoptimalkan daya pikir rasionalnya melalui belajar mengemukakan pendapat, mencoba memecahkan masalah dan menarik kesimpulan sederhana.

Pembelajaran blended learning merupakan pendekatan pembelajaran campuran antara pembelajaran tatap muka biasa (classroom face-to face) dengan pembelajaran tatap muka dunia maya (online face-to face), dimana sumber pembelajaran, berupa uraian materi pembelajaran, tugastugas, maupun tes yang dapat berupa teks, gambar, suara, maupun video ditaruh di internet sehingga dapat diakses mahasiswa 24 jam. YouTube misalnya adalah salah satu sumber yang kaya untuk klip video animasi dan film pendek yang akan menantang mahasiswa untuk menonton dengan hati-hati dan terlibat dalam berpikir dan belajar statistik. Sumber yang kaya ini dapat dijadikan dosen sebagai sumber 
pembelajaran dengan menggunakan pendekatan blended learning. Pendidikan di Negara barat kecenderungan pembelajaran dengan blended learning bahkan penerapan online learning semakin meningkat dalam satu dekade terakhir ini. Seperti Amerika Serikat telah memproyeksikan bahwa pada tahun 2014 lebih dari $80 \%$ dari jumlah mahasiswa mereka pada perguruan tinggi telah mengambil sekurangkurangnya satu mata kuliah online (Maarop \& Embi, 2016). Berdasarkan survei yang dilakukan oleh (Hilliard, 2015) bahwa pertumbuhan budaya belajar blended learning telah mencapai angka $46 \%$ per tahun di seluruh dunia, begitu pun di Indonesia pemerintah telah mencanangkan pembelajaran berbasis TIK sejak lebih dari satu dasa warsa terakhir.

Pada tatanan praktis blended learning tentu memberikan ruang yang cukup bagi mahasiswa untuk melihat potensi dirinya sendiri, melalui ruang pembelajaran tatap muka mahasiswa dikondisikan dan dibina sedangkan melalui ruang maya akan membentuk karakter dirinya yang mandiri. Kemandirian belajar menunjukkan bahwa sesorang peserta didik mempunyai rasa tanggung jawab terhadap keberhasilan dalam belajar. Menurut Prayuda (2014: 5) kemandirian belajar merupakan suatu sikap kepercayaan diri yang tinggi, mempunyai inisiatif untuk mengatasi suatu masalah dan bertanggung jawab atas tugas-tugas yang diperintahkan, sehingga pada akhirnya akan membuat peserta didik menjadi siap untuk belajar sepanjang hayat dan mempunyai kemampuan adaptasi dalam proses pembelajaran. Menurut Takdir (2012: 188) indikator kemandirian belajar meliputi : 1) inisiatif belajar, 2) mendiagnosa kebutuhan belajar, 3) menetapkan target atau tujuan belajar, 4) mengontrol belajar, 5) memanfaatkan dan mencari sumber yang relevan, 6) memilih dan menetapkan startegi belajar, 7) mengevaluasi proses dan hasil belajar.

Hasil belajar merupakan tolak ukur untuk mengetahui keberhasilan mahasiswa dalam menguasai pelajaran setelah mengikuti proses pembelajaran. Sesuai pernyataan Hamalik (2010:21) menyatakan bahwa: Hasil belajar adalah tingkah laku yang timbul misalnya dari yang tidak tahu, timbulnya pengertian baru, perubahan setiap kebiasaan, keterampilan, kesanggupan, menghargai perkembangan sifat-sifat sosial, emosional dan pertumbuhan jasmani. Hasil belajar dapat berupa keterampilan, nilai, sikap mahasiswa dan dapat digunakan untuk melihat sejauh mana tujuan-tujuan instruksional telah dapat dicapai atau dikuasai oleh mahasiswa yang diperlihatkan setelah mereka menempuh pengalaman belajarnya. Pada penelitian ini peneliti akan 
melihat hasil belajar mahasiswa pada ranah kemampuan berpikir secara rasional.

Kemampuan berpikir rasional ini dianggap sangat penting oleh para ahli karena berhubungan erat dengan kehidupan sehari-hari mahasiswa. Berdasarkan kajian literatur (Novak, 1979; Ausuble dalam Lawson, 1979; Suciati, 2015) menyatakan bahwa kemampuan berpikir rasional sangat dibutuhkan dalam pemecahan masalah, terutama untuk masalah sehari-hari yang tidak terlalu sulit. Dalam pembelajaran berpikir rasional dimaknai sebagai pemrosesan informasi secara sadar dan logis, pemikiran seperti ini dibutuhkan mahasiswa untuk menganalisis dan mempertimbangkan informasi yang diperoleh untuk menghasilkan sebuah pengetahuan utuh (Syah, 2013; Epstein dalam Curtis, et.,al, 2013).

Indikator

yang menggambarkan

kemampuan berpikir rasional dikeluarkan oleh The Educational Policies Commision, dijelaskan oleh (Novak, 1979; Ausuble dalam Lawson, 1979) sebagai berikut ; mengingat, membayangkan, mengelompokkan, menggeneralisasikan,

membandingkan, mengevaluasi, menganalisis, mensintesis, mendedukasikan, membuat kesimpulan. Proses berpikir seperti yang digambarkan dengan 10 indikator di atas disebut kekuatan rasional yang memungkinkan seseorang untuk menerapkan logika dan bukti yang tersedia untuk ide-ide yang diungkapkannya, menentukan sikap dan tindakan dengan cara yang wajar dapat diterima orang lain.

\section{METODE PENELITIAN}

Jenis penelitian ini merupakan penelitian tindakan kelas karena penelitian ini bertujuan untuk meningkatkan hasil dan aktivitas belajar mahasiswa pendidikan akuntansi yang mengambil mata kuliah Statistika penelitian dan dilakukan perbaikan terhadap proses pembelajaran secara terus menerus selama penelitian. Subjek dari penelitian ini adalah mahasiswa semester VI kelas A pendidikan akuntansi yang mengambil mata kuliah statistik penelitian semester genap tahun ajaran 2017/2018 yang berjumlah 42 orang.

Prosedur penelitian PTK ini terbagi atas 4 tahap, yaitu :

1. Tahap Perencanaan

Langkah-langkahnya adalah :

a. Merancang pembagian materi yang akan dibahas pada pertemuan tatap muka dan pembelajaran jarak jauh

b. Merancang sumber belajar

c. Merancang kelompok belajar mahasiswa pada pertemuan tatap muka berdasarkan keheterogenan kemampuan kognitif.

d. Merancang latihan soal 
e. Mempersiapkan alokasi waktu untuk mengerjakan latihan soal statistik secara berkelompok pada pertemuan tatap muka

f. Mempersiapkan alokasi waktu untuk pembahasan soal latihan
2. Tahap Pelaksanaan Tindakan

Langkah-langkah yang akan dilakukan adalah :

Tabel 2. Rancangan Pelaksanaan Tindakan Blended Learning

\begin{tabular}{|l|l|}
\hline \multicolumn{1}{|c|}{ Siklus I } & \multicolumn{1}{|c|}{ Siklus II } \\
\hline Capaian Pembelajaran Mata Kuliah & Capaian Pembelajaran Mata Kuliah \\
(CPMK): & (CPMK): \\
Mahasiswa mampu menggunakan & Mahasiswa mampu menggunakan \\
rumus statistik pengujian hipotesis & rumus statistik pengujian hipotesis \\
komparatif & asosiatif \\
Sub Capaian Pembelajaran Mata Kuliah & Sub Capaian Pembelajaran Mata Kuliah \\
(Sub-CPMK): & (Sub-CPMK): \\
Mahasiswa mampu menggunakan & Mahasiswa mampu menggunakan \\
rumus statistik untuk pengujian & rumus statistik untuk pengujian \\
hipotesis komparatif & hipotesis asosiatif \\
Materi : & Materi : Uji Hipotesis asosiatif \\
Uji hipotesis komparatif & Definisi uji hipotesis asosiatif \\
Definisi uji hipotesis komparatif & Rumus statistik parametris \\
Uji hipotesis dua sampel & Rumus statistik non parametris \\
\hline Tatap Muka & Tatap Muka \\
\hline Langkah-Langkah Pembelajaran : & Langkah-Langkah Pembelajaran : \\
Awal (10 Menit) : Absesi, apersepsi, \\
memotivasi mahasiswa melalui tanya \\
jawab dan menyampaikan tujuan
\end{tabular}$\quad \begin{aligned} & \text { Awal (10 Menit) : Absesi, apersepsi, } \\
& \text { perkuliahan }\end{aligned}$




\begin{tabular}{|c|c|}
\hline $\begin{array}{l}\text { Membahas soal bersama-sama } \\
\text { Akhir (10 Menit) : } \\
\text { Menyimpulkan makna dan konsep dari } \\
\text { materi perkuliahan yang telah dipelajar }\end{array}$ & $\begin{array}{l}\text { terkait secara mandiri oleh kelompok } \\
\text { Membahas soal bersama-sama } \\
\text { Akhir (10 Menit) : } \\
\text { Menyimpulkan makna dan konsep dari } \\
\text { materi perkuliahan yang telah dipelajari }\end{array}$ \\
\hline $\begin{array}{l}\text { Evaluasi : Penilaian pencapaian belajar } \\
\text { mahasiswa dilakukan selama proses } \\
\text { belajar dengan cara memberikan } \\
\text { pertanyaan secara lisan, dan pemberian } \\
\text { soal pada akhir siklus }\end{array}$ & $\begin{array}{l}\text { Evaluasi : Penilaian pencapaian belajar } \\
\text { mahasiswa dilakukan selama proses } \\
\text { belajar dengan cara memberikan } \\
\text { pertanyaan secara lisan, dan pemberian } \\
\text { soal pada akhir siklus }\end{array}$ \\
\hline Jarak Jauh & Jarak Jauh \\
\hline $\begin{array}{l}\text { Pemberian soal latihan lanjutan pada } \\
\text { akhir perkuliahan tatap muka } \\
\text { Mahasiswa mengerjakan tugas secara } \\
\text { mandiri atau bersama-sama diluar jam } \\
\text { perkuliahan } \\
\text { Tanya jawab (konsultasi atau berbagi } \\
\text { informasi) melalui jejaring sosial } \\
\text { berbentuk chat group whatsapp } \\
\text { Mengumpulkan latihan maksimal dua } \\
\text { hari setelah perkuliahan tatap muka, } \\
\text { dikirim melalui email masing-masing. }\end{array}$ & $\begin{array}{l}\text { Pemberian soal latihan lanjutan melalui } \\
\text { jejaring sosial chat group whatsapp } \\
\text { Mahasiswa mengerjakan tugas secara } \\
\text { mandiri atau bersama-sama diluar jam } \\
\text { perkuliahan } \\
\text { Tanya jawab (konsultasi atau berbagi } \\
\text { informasi) melalui jejaring sosial } \\
\text { berbentuk chat group whatsapp } \\
\text { Mengumpulkan latihan tanpa batas } \\
\text { waktu maksimal }\end{array}$ \\
\hline
\end{tabular}

Sumber: Dari Ringkasan RPS

\section{Tahap Pengamatan}

Pada saat melakukan tindakan peneliti minta bantuan teman sejawat untuk menjadi observer. Selama pembelajaran berlangsung observer melakukan pengamatan terhadap semua kegiatan mahasiswa, bagaimana kesiapan dalam pembelajaran, reaksi mahasiswa terhadap penggunaan media, konsentrasi selama pembelajaran, frekuensi mahasiswa bertanya dan menanggapi, berapa lama waktu yang digunakan dalam mengerjakan soal evaluasi. Selain itu observer juga berperan untuk mengamati dan mencatat semua yang dilakukan dosen dalam pembelajaran apakah sudah sesuai dengan perencanaaan, jika belum sesuai maka akan didiskusikan pada tahap refleksi.

\section{Tahap Refleksi}

Setelah kegiatan inti, berdasarkan data hasil observasi dan evaluasi pembelajaran peneliti melakukan refleksi untuk menilai sejauh mana keefektifan penggunaan media gambar. Selain itu juga mencari solusi atas hambatanhambatan yang muncul untuk perbaikan pada kegiatan siklus 
berikutnya

Selanjutnya

dosen/peneliti menganalisis hasil pengamatan atas tindakan dosen dan perilaku mahasiswa serta korelasinya dengan ketercapaian tujuan pembelajaran. Apabila hasil belajar siawa berdasarkan kriteria ketuntasan Minimal belum mencapai indikator keberhasilan yang sudah ditetapkan, yaitu $\geq 75 \%$, maka penelitian tindakan dilanjutkan. Jika hasil penilaian sudah mencapai indikator keberhasilan maka penelitian tindakan dianggap berhasil sesuai dengan rencana hanya 2 siklus.

Instrumen penelitian adalah Lembaran tes kemampuan berpikir rasional. Lembaran ini digunakan untuk mengukur keberhasilan mahasiswa setelah mengikuti kegiatan pembelajaran setiap akhir siklus. Tes hasil belajar yang disusun adalah berbentuk uraian sebanyak 10 soal. Data yang dianalaisis dalam penelitian ini adalah data tes kemampuan berpikir rasional mahasiswa dari hasil tes setiap akhir siklus. Data hasil belajar mahasiswa yang diperoleh dari tes yang dilaksanakan setelah berakhir satu siklus, dianalisis untuk melihat ketuntasan belajar mahasiswa secara individu atau mendapatkan nilai $\geq B$. Dalam penelitian ini diharapkan hasil belaja rmahasiswa yang memenuhi nilai $\geq \mathrm{B}$ dapat melebihi $75 \%$ dari jumlah mahasiswa. Ketuntasan belajar mahasiswa secara individu dapat dihitung dengan menggunakan rumus :

$$
N I=\frac{T}{S M} \times 100
$$

Keterangan :

$\mathrm{NI}=$ Ketuntasan belajar secara individu

$\mathrm{T}=$ Skor yang diperoleh mahasiswa $\mathrm{SM}=$ Skor maksimum dari tes

\section{HASIL PENELITIAN}

a. Deskripsi Kondisi Awal

Kondisi awal sebelum tindakan, dapat peneliti sampaikan melalui tabel daftar ringkasan nilai tes formatif mahasiswa (melalui kuis) dengan soal yang sesuai pola berpikir rasional, berikut:

Tabel 3. Hasil Tes Awal Kemampuan Berpikir Rasional

\begin{tabular}{|c|c|c|c|}
\hline No & Uraian & Kemandirian belajar & $\begin{array}{c}\text { Kemampuan berpikir } \\
\text { rasional }\end{array}$ \\
\hline 1 & Nilai tertinggi & Sedang & 80 \\
\hline 2 & Nilai terendah & Rendah & 40 \\
\hline 3 & Nilai Rata-Rata & Sedang & 60 \\
\hline
\end{tabular}

Sumber: Dari Olah Data Penelitian

Berdasarkan tabel di atas dapat diketahui bahwa kondisi awal hasil belajar berpikir rasional mahasiswa masih rendah, hanya $15 \%$ mahasiswa 
yang mendapatkan skor diatas 70 . Hal demikian diindikasi salah satu sebabnya adalah penerapan metode yang digunakan dosen belum mampu mengkondisikan mahasiswa untuk belajar efektif dan sesuai kemampuan masing-masing, sehingga pembelajaran belum memberikan makna mendalam bagi sebagian mahasiswa. b. Deskripsi Hasil Siklus I

Pelaksanaan perbaikan siklus I berjalan cukup baik, dari hasil pengamatan observer pembelajaran dengan blended learning sudah sesuai dengan rencana pembelajaran yang telah dibuat. Berikut ini data dari tes kemampuan berpikir rasional mahasiswa pada siklus I,

Tabel 4. Hasil Tes Siklus I Kemampuan Berpikir Rasional

\begin{tabular}{|c|c|c|c|}
\hline No & Uraian & $\begin{array}{c}\text { Kemandirian } \\
\text { belajar }\end{array}$ & $\begin{array}{c}\text { Kemampuan berpikir } \\
\text { rasional }\end{array}$ \\
\hline 1 & Nilai tertinggi & Sedang & 85 \\
\hline 2 & Nilai terendah & Rendah & 55 \\
\hline 3 & Nilai Rata-Rata & Sedang & 70 \\
\hline
\end{tabular}

Keterangan : Jumlah mahasiswa : 42 orang

Tuntas

: 15 mahasiswa

Tidak tuntas

Tindak lanjut
: 27 mahasiswa

: Perbaikan siklus II
Perbaikan pembelajaran siklus

I ini yang peneliti amati dari mahasiswa adalah aktivitas dalam mengikuti pembelajaran, mendengarkan, menanggapi pertanyaan serta mengajukan pertanyaan terkait materi yang sedang dibahas. Dilihat juga kemampuan mahasiswa untuk mengerjakan latihan soal statistik yang sama dengan yang sudah dosen ajarkan sebelumnya, kemudian dibahas bersama-sama didepan kelas, serta kemampuan mahasiswa menyelesaikan soal-soal yang diberikan pada saat evaluasi pembelajaran. Dari data yang diperoleh, tampak bahwa mahasiswa yang tuntas dengan skor di atas 70 baru mencapai $35 \%$ dari total mahasiswa.

Untuk siklus I ini pembelajaran blended learning diselenggarakan dengan motode tatap muka seperti biasa dengan metode diskusi kelompok kecil dan latihan soal, kelompok dipilihkan oleh dosen dan soal latihan dibagikan secara acak, setiap soal latihan. Kendala yang muncul pada siklus I yaitu keadaan kelas sedikit gaduh ketika mahasiswa diminta untuk mengerjakan soal latihan bersama-sama, sebagian mahasiswa masih sibuk bermainmain dengan handphone dan tidak memperhatikan instruksi, sehingga 
pada saat mengerjakan mereka tidak mengerti dan hanya mengandalkan teman dalam kelompoknya.

Metode kedua yang diterapkan dalam penelitian tindakan ini ialah pembelajaran jarak jauh, dimana latihan-latihan soal yang belum selesai dikerjakan pada jam tatap muka harus dikerjakan mahasiswa secara berkelompok diluar jam perkuliahan. Hasil pekerjaan c. mahasiswa harus dikumpulkan maksimal 2 hari setelah tatap muka berlangsung, pengiriman hasil latihan dilakukan via email. Pada pembelajaran jarak jauh mahasiswa tetap difasilitasi untuk berdiskusi dengan dosen yang bersangkutan melalui chat group whatsapp. Namun banyak sekali kendala yang dihadapi mahasiswa dalam mengerjakan tugas latihan mandiri jarak jauh ini, karena belum terlalu paham dengan langkah pengerjaan soal yang telah dosen jelaskan pada saat tatap muka, maka mahasiswa merasa sulit menyelesaikan latihan mandirinya, selain itu ada sebagian mahasiswa yang tidak membantu kelompoknya mengerjakan, tugas hanya dipertanggung jawabkan oleh sebagian kecil dari kelompoknya.

Untuk itu maka penelitian tindakan dilanjutkan ke siklus II dengan catatan bahwa kelompok belajar dipilih sendiri oleh mahasiswa, mekaisme pengerjaan soal dibuat berbentuk instruksi video yang didapat dari youtube dan harus dishare melalui group whatsapp, sehingga tiap mahasiswa memilikinya. Tugas-tugas mahasiswa dalam kelompok harus jelas, baik bagian penanya, pencari tutorial dan beberapa orang yang mengoperasikan komputer dalam mengerjakan latihan.

Deskripsi Hasil Siklus II

Berdasarkan hasil analisis data siklus I, didapati $65 \%$ skor mahasiswa masih dibawah 70. Maka penelitian tindakan harus dilanjutkan ke siklus II. Pelaksanaan perbaikan siklus II berjalan baik, dari hasil pengamatan observer pembelajaran dengan metode diskusi kelompok kecil dan laihan mandiri ini sudah sesuai dengan rencana pembelajaran yang telah dibuat. Mahasiswa diminta secara mandiri mengelompokkan diri masingmasing dalam delapan bagian kelas. Diwajibkan bagi setiap kelompok memiliki minimal dua buku statstik penelitian dan setiap kelompok mahasiswa wajib memiliki tiga handphone dengan paket internet stabil.

Berikut ini data dari tes kemampuan berpikir rasional mahasiswa pada siklus II pembelajaran dengan blended learning, 
Tabel 5.Hasil Tes Siklus II Kemampuan Berpikir Rasional

\begin{tabular}{|c|c|c|c|}
\hline No & Uraian & $\begin{array}{c}\text { Kemandirian } \\
\text { belajar }\end{array}$ & $\begin{array}{c}\text { Kemampuan } \\
\text { berpikir rasional }\end{array}$ \\
\hline 1 & Nilai tertinggi & Tinggi & 100 \\
\hline 2 & Nilai terendah & Rendah & 65 \\
\hline 3 & Nilai Rata-Rata & Sedang & 85 \\
\hline
\end{tabular}

Keterangan : Jumlah mahasiswa : 42 orang

Tuntas : 35 orang

Tidak tuntas : 7 orang

Tindak lanjut : dari 42 mahasiswa semester IV kelas A hanya 7 mahasiswa yang belum tuntas mendapatkan skor 70, jika dipersentasekan $83 \%$ mahasiswa yang tuntas, maka perbaikan pembelajaran bisa dikatakan berhasil dan tidak akan dilanjutkan ke siklus III.

\section{PEMBAHASAN}

Pelaksanaan pembelajaran statistik penelitian kelas A semester IV sudah berjalan sebagaimana telah direncanakan, secara keseluruhan teori-teori yang diajukan dalam penelitian ini dapat dibuktikan dilapangan. Penerapan model blended learning untuk meningkatkan kemampuan berpikir rasional terbilang baik, karena hakikatnya berpikir rasional erat kaitannya dengan pemecahan masalah secara mandiri dan pengambilan keputusan dengan pertimbangan yang matang. Dalam kehidupan sehari-hari mahasiswa dihadapkan dengan permasalahan rill yang membutuhkan pemikiran rasional untuk menyelesaikannya. Kemampuan berpikir rasional mahasiswa berkembang sejalan dengan perkembangan kognitifnya, maka peran dosen dikelas sangat dibutuhkan untuk menyediakan pengalaman belajar yang menuntut keterlibatan aktif dan kreativitas berpikir.

Menurut teori perkembangan kognitif Piaget (Trianto 2010:29) perkembangan kognitif sebagian besar ditentukan oleh manipulasi dan interaksi aktif mahasiswa dengan lingkungan belajarnya. Belajar tidak hanya pemerolehan informasi, melainkan sebagai pemberian makna oleh mahasiswa terhadap pengalamannya melalui proses asimilasi dan akomodasi yang bermuara pada pemutakhiran struktur kognitifnya. Terhadap informasi yang diberikan mahasiswa tidak hanya pasif menerima, melainkan berperan aktif menyusun 
pengetahuan mengenai realitas di sekelilingnya.

Pemilihan

metode

pembelajaran yang tepat akan sangat berpengaruh perkembangan kognitif dan pola pikir mahasiswa. Dosen harus mampu menerapkan metode yang membentuk situasi belajar menjadi menantang kreativitas berpikir. Seperti blended learning dosen membiasakan mahasiswa untuk mendalami sebuah masalah dan belajar mencari pemecahannya. Melalui bimbingan dosen dalam setiap tahapan pembelajaran, mahasiswa dibiasakan untuk bertanya dan mengemukakan pendapat secara logis. Melalui blended learning kemampuan berpikir rasional mahasiswa secara kontinue akan meningkat, karena dalam penyelesaian masalah dengan rasional basisnya adalah logis dan beralasan sedangkan blended learning basis pembelajarannya ialah penemuan logis, nyata, beralasan dan bebas.

Berdasarkan data hasil penelitian kemampuan berpikir rasional mengalami peningkatan selama tindakan perbaikan pembelajaran dengan metode blended learning berlangsung. Peningkatan tersebut dapat dilihat pada diagram berikut:

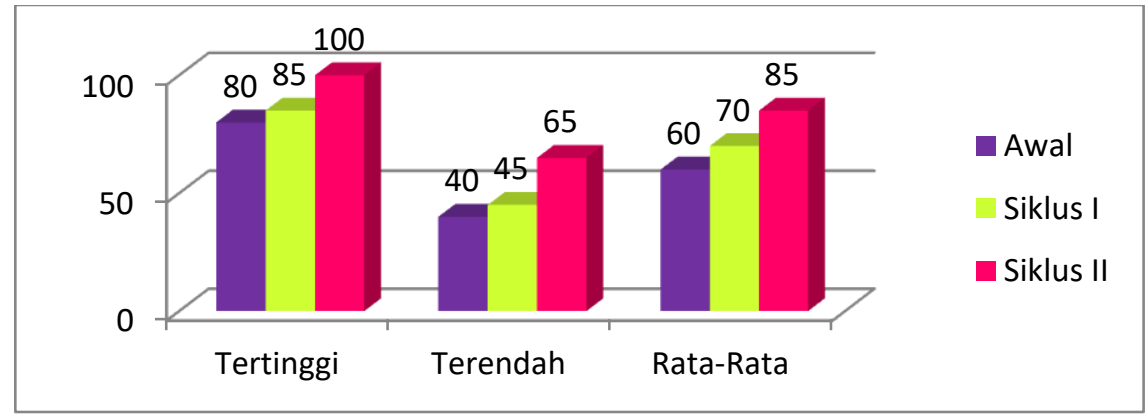

Gambar 1. Peningkatan Kemampuan Berpikir Rasional

Gambar di atas menjelaskan peningkatan kemampuan berpikir rasional mahasiswa pada setiap siklus, dimana pada refleksi awal kemampuan berpikir rasional mahasiswa masih sangat rendah, nilai tertinggi pun hanya 5 angka di atas kriteria ketuntasan. Namun seiring dengan dilakukannya perbaikan pembelajaran dengan metode blended learning kemampuan berpikir rasional mahasiswa semakin meningkat, bahkan pada siklus ke II ada 7 orang yang mendapatkan nilai maksimum yaitu 100 .

Peningkatan kemampuan berpikir rasional mahasiswa, pada skor tertinggi, terendah serta skor rata-rata sedikit demi sedikit meningkat dinamis sejalan dengan semakin membaiknya suasana belajar di kelas. Berikut ini dapat dilihat perbedaan tiap skor yang 
dijadikan tolak ukur peningkatan kemampuan berpikir rasional mahasiswa pada mata kuliah statistik penelitian semester IV dari refleksi awal, pembelajaran siklus I dan siklus II. Membaca diagram di atas, tampak jelas terlihat peningkatan kemampuan mahasiswa pada tiap siklus semakin membaik, sejalan dengan membaiknya suasana belajar dan peran mahasiswa dalam mengikuti proses belajar. Dapat dilihat untuk nilai tertinggi dari refleksi awal ke siklus I meningkat $6,26 \%$, hal ini menunjukkan kemajuan yang cukup baik, disisi lain dosen juga merasa melalui pembelajaran blended learning materi statistik lebih mudah dipahami mahasiswa. Sedangkan pada siklus II nilai tertinggi meningkat $17,65 \%$ dari siklus I, angka skor 100 menunjukkan kemampuan berpikir rasional yang sangat baik, mahasiswa mampu mengerjakan 10 soal statistik dengan benar. Sepanjang proses perbaikan tentunya ini merupakan angka yang fantastis dan hasil belajar terbaik yang diperoleh mahasiswa.

Hal yang sama pada nilai terendah mahasiswa sedikit demi sedikit meningkat dan membaik seiring dengan membaiknya suasana pembelajaran. Dari refleksi awal ke siklus I meningkat $12,5 \%$, tentu angka ini menunjukkan hal yang positif, respon baik dari diri dan kognitif mahasiswa terhadap materi yang diajarkan tampak dalam upaya keras mahasiswa dalam menyelesaikan soal-soal latihan. Namun penelitian tindkaan ini belum cukup sampai siklus I saja berhubung masih ada sekitar 64\% mahasiswa yang belum tuntas. Pada siklus II nilai terendah meningkat $44,4 \%$ dari siklus I, angka ini menunjukkan perbaikan yang optimal, meski nilai terendah masih berada di bawah ketuntasan minimum namun secara keseluruhan nilai mahasiswa sudah sangat baik. Nilai rata-rata dari refleksi awal ke siklus I meningkat $16,7 \%$ sedangkan pada siklus II nilai rata-rata meningkat $21,4 \%$ dari siklus I.

Variabilitas kemampuan berpikir rasional yang terjadi dalam penelitian ini disamping adanya pengaruh dari metode pembelajaran yang terapkan dalam tindakan, ada faktor lain yang tidak mungkin dikesampingkan, yaitu kemandirian belajar. Kemandirian belajar mempengaruhi minat mahasiswa terhadap kegiatan pembelajaran yag berlangsung, hampir sebagian besar mahasiswa akan menjadi aktif di kelas ketika cara dosennya menyampaikan materi sesuai dengan ketertarikan dirinya. Seperti halnya kemampuan berpikir rasional mahasiswa pada mata kuliah statistik penelitian, pada kelompok mahasiswa yang memiliki kemandirian belajar tinggi yang diajar dengan model blended learning ini nampak sangat tertarik dan antusias mengikuti perkuliahan, 
karena mereka merasa memiliki ruang yang lebih luas dari biasanya untuk mengambil peran dalam pembelajaran. Sejalan dengan pendapat (Takdir: 2012) bahwa anak yang memiliki kemandirian belajar tinggi akan lebih mudah memahami informasi yang ia temukan dan buktikan sendiri. Kelompok mahasiswa dengan kemandirian belajar tinggi lebih suka menjadi pemroses dan pencari informasi.

Sepanjang pembelajaran blended learning mahasiswa dikondisikan sebagai pencari informasi secara mandiri melalui buku, internet dan lain-lain, sehingga perannya akan meningkat lebih aktif dari biasanya. Begitu pula pada saat pembelajaran jarak jauh, kelompok mahasiswa dengan kemandirian tinggi akan belajar seperti biasanya ia belajar mandiri selama ini.

Selanjutnya kemampuan berpikir rasional mahasiswa pada mata kuliah statistik penelitian pada kelompok mahasiswa yang memiliki kemandirian belajar sedang yang diajar dengan metode blended learning menunjuk antusias dan hasil belajar yang baik. Hal ini mendukung pendapat (Takdir: 2012), mahasiswa dengan kemandirian belajar sedang cenderung lebih menyukai kegiatan pembelajaran yang melibatkan diri mereka namun tidak bisa dibiarkan bekerja sendiri selamanya. Pada pembelajaran blended learning mahasiswa posisikan sebagai seorang pencari informasi secara mandiri, peneliti dan pembahas, namun tetap dibawah bimbingan dan arahan dari dosen pengampuh mata kuliah. Kegiatan pembelajaran seperti inilah yang sangat sesuai dengan kriteri kemandirian belajar sedang, sedangkan pada pembelajaran.

Lebih lanjut (Takdir: 2012) telah menjelaskan mahasiswa yang memiliki kemandirian belajar rendah lebih suka diajak belajar dengan instruksi langsung dari dosen yang bersangkutan. Pada pembelajaran blended learning ini mahasiswa yang memiliki kemandirian belajar rendah tetap akan difasilitasi sesuai ketertarikannya diawal, namun sedikit demi sedikit kelompok ini menunjukkan perubahan yang lebih baik. Blended learning memasukkan dua unsur pembelajaran dalam satu model yaitu tatap muka dan jarak jauh, tentunya kegiatan pembelajaran tatap muka ini difokuskan untuk mewadahi mahasiswa yang belum mandiri dalam belajar dan pembelajaran jarak jauh akan menjadi wahana latihan bagi kelompok mahasiswa ini untuk menjadi pribadi belajar yang mandiri.

Kemampuan berpikir rasional mahasiswa pada mata kuliah statistik penelitian pada kelompok kemandirian belajar rendah cukup mampu mengikuti pembelajaran blended learning. Dalam upaya memecahkan masalah latihan soal, mahasiswa akan diperkenalkan 
dengan berbagai macam informasi dalam bacaan yang berbeda dari buku, internet dan majalah, hal ini akan memancing atensi belajar dan membiasakan mahasiswa dengan kemandirian belajar rendah ini untuk berperan dan aktif membangun pengetahuan sendiri dengan caranya. Untuk lebih jelasnya melihan peningkatan kemandirian belajar mahasiswa selama tindakan perbaikan pembelajaran dua siklus, perhatikan gambar berikut :

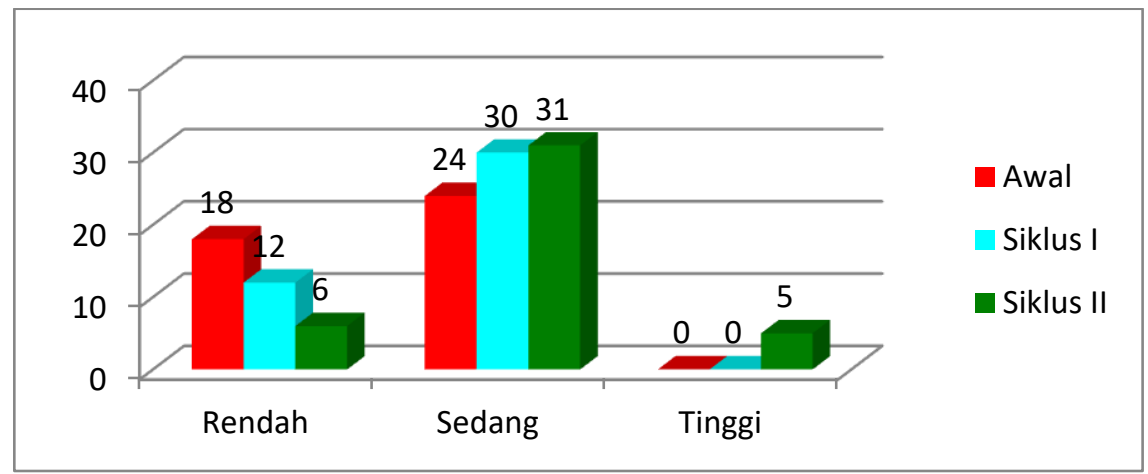

Gambar 2. Peningkatan Kemandirian Belajar

Membaca diagram 4.2 di atas, tampak jelas terlihat peningkatan kemandirian belajar mahasiswa pada tiap siklus semakin membaik, sejalan dengan membaiknya peran mahasiswa dalam belajar dan berkat adanya pembelajaran jarak jauh pada blended learning. Dapat dilihat kelompok mahasiswa dengan kemandirian rendah berkurang untuk setiap siklus, artinya sebagian mahasiswa telah berubah menjadi mahasiswa yang lebih mandiri berkat blended learning. dari refleksi awal ke siklus I berkurang sebanyak $33,3 \%$, hal ini menunjukkan kemajuan yang cukup baik, Sedangkan pada siklus II kelompok mahasiswa yang memiliki kemandirian belajar rendah berkurang $50 \%$ dari siklus I. Sepanjang proses perbaikan pembelajaran dengan blended learningmahasiswa diberikan ruang untuk belajar seperti yang diinginkan, mencari informasi dan memproses informasi secara mandiri sehingga mahasiswa akan terbiasa mengerjakan segala sesuatu sendiri.

Hal yang sama pada kelompok mahasiswa dengan kemandirian belajar sedang, sedikit demi sedikit meningkat seiring penerapan blended learning. Dari refleksi awal ke siklus I meningkat $25 \%$, tentu angka ini menunjukkan hal yang positif, pada siklus II kelompok kemandirian belajar sedang meningkat 3,3\% dari siklus I. sedangkan untuk kelompok mahasiswa dengan kemandirian belajar tinggi hanya terdapat pada siklus II yaitu 2,1\% dari keseluruhan mahasiswa yang mengambil mata kuliah statistik penelitian. 
Berdasarkan pemaparan di atas secara umum penelitian tindakan ini telah mampu menjawab rumusan masalah dan mencapai tujuan yang diharapkan. Penelitian ini dapat dikatakan berhasil karena semua kriteria yang ditentukan telah terpenuhi. Dengan belnded learning semua kemampuan mahasiswa telah terfasilitasi, baik mahasiswa yang sangat mandiri sampai mahasiswa yang malas belajar pun sudah mampu beradaptasi dengan pola perkuliahan, meningkatkan minat belajar serta mengurangi rasa tegang dalam pembelajaran

Penggunaan metode pembelajaran blended learning di kelas dapat memberikan beberapa keuntungan nyata bagi dosen dan mahasiswa. Bagi dosen blended learning sangat membantu dirinya dalam mengorganisasikan materi statistik yang notabennya terdiri dari rumus dan perhitungan. Selama ini statistik dianggap mata kuliah yang sulit dijelaskan dan membutuhkan durasi belajar yang panjang untuk menyelesaikan satu latihan soal dengan instruksi langsung dari dosen. Keuntungan bagi mahasiswa pada saat dilaksanakannya pembelajaran blended learning, mahasiswa tidak dilarang menggunakan gadget saat perkuliahan berlangsung, mahasiswa bebas mencari informasi dari mana saja dan mengekspresikan pendapatnya tanpa kekhawatiran mendapat sanksi. Mereka dapat pula mengurangi dan mendiskusikan isuisu yang bersifat manusiawi dan pribadi tanpa adanya kecemasan. Blended learning memungkinkan mahasiswa mengidentifikasi dan mendiskusikan situasi-situasi dunia nyata aktual yang ditemui diinternet, sehubungan dengan pengembangan kemampuan berpikir rasional mahasiswa. Identifikasi tersebut memungkin mahasiswa belajar lebih banyak dan lebih luas dari sekedar memahami perhitungan statistik.

\section{KESIMPULAN}

Berdasarkan hasil penelitian dan pembahasan maka dapat disimpulkan bahwa Hasil belajar kemampuan berpikir rasional mahasiswa dengan menggunakan model blended learning meningkat dari siklus I ke siklus II dan mencapai target dalam penelitian ini yaitu $75 \%$ dari jumlah mahasiswa di kelas memperoleh nilai $\geq \mathrm{B}$. Sehubungan dengan hasil penelitian yang telah diperoleh maka peneliti memberikan saran kepada dosendosen dapat menggunakan metode blended learning ini dalam pembelajaran statistik penelitian dan pembelajaran lainnya yang membutuhkan waktu yang relatif panjang, karena blended learning ini merupakan sebuah pembelajaran tanpa batas jarak dan waktu namun tetap dalam pengawasan dosen yang bersangkutan. 


\section{DAFTAR PUSTAKA}

Baron, Jonathan. 2008. Thinking and Deciding, Fourth Edition. New York: Cambridge University Press

Curtis, et.,al. (2013). Connecting Cognitive- Experiential SelfTheory's InformationProcessing Styles With Organisational- Influencing Tactics: Rational Thinkers are Rational Persuaders. The Australian and New Zealand Journal of Organisational Psychology, 6 (2) 1-11

Hamalik, Oemar. 2010. Belajar dan Foktor-Faktor yang Mempengaruhi. Jakarta : Bumi Aksara

Hilliard, A. T. (2015). Global Blended Learning Practices for Teaching and Learning, Leadership and Professional Development. Journal of International Education Research, 11(3), 179-188.

Lawson. (1979). AETS Yearbook: The Psychology of Teaching for Thinking and CreativLty. Columbus, Ohio: Association for the Education of Teachers in Science: ERIC [online] Diakses pada : 05 Desember 2016

Maarop, A. H., \& Embi, M. A. (2016). Implementation of Blended Learning in Higher Learning Institutions: A Review of Literature. ResearchGate, 9(3), 41. https://doi.org/10.5539/ies.v9n3 p41 Diakses pada : 05 Desember 2016

Novak, D., Joseph. (1979). Meaningful Reception Learning As a Basic for Rational Thinking. Cozumel University. [online] Diakses pada : 05 Desember 2016

Prayuda, R. (2014). Pengaruh Kemandirian Belajar Terhadap Hasil Belajar Siswa Pada Mata Pelajaran Ekonomi Di SMA. Artikel Penelitian : Program Studi Pendidikan Ekonomi BKK Koperasi FKIP Untan.

Suciati. (2015). Psikologi Komunikasi, Sebuah Tinjauan Teoritis dan Perspektif Islam. Yogyakarta; Buku Litera Yogyakarta.

Syah, Muhibbin. (2013). Psikologi Pendidikan dengan Pendekatan Baru. Bandung; Remaja Rosdakarya

Takdir. (2012). Pembelajaran Discovery Strategy \& Mental Vocational Skill. Jogjakarta: Banguntapan.

Trianto.(2010). Mendesain Model Pembelajaran InovatifProgresif Konsep, Landasan dan Implementasinya pada Kurikulum Tingkat Satuan Pendidikan (KTSP). Jakarta : Kencana 